\title{
Phenomenon of Changes in Increasing Development of Students in Basic School
}

\author{
Binti Muliati, Muhamad Khoirul Umam \\ Education Faculty, The College of Badrus Sholeh, Purwoasri, Kediri, East Java, Indonesia
}

\begin{abstract}
This writing aims to describe the development of social deviation in children who live with the environment that experienced problems of reading and counting. The development of children include the association of children with peers and children's play activities. This writing uses a qualitative approach to case study design with elementary school students living with social environment. Data collection techniques in this paper using observation techniques, interviews, and documentation. The data obtained were analyzed by analytical techniques using data reduction measures, data presentation, and conclusions. Testing the validity of the data using the credibility test by doing triangulation, reference materials, and member check. The results of the writing show that seen from the relationship of social environment. For some children, subjects fall into the category of neglected children. But for some other children, subjects fall into the category of rejected children. From the aspect of activity, giving rise to unique behavior in elementary school children. The subject, however, does not play a less active behavior in the social environment.
\end{abstract}

Keywords: development, elementary school children

\begin{abstract}
Abstrak
Tulisan ini bertujuan untuk menggambarkan penyimpangan perkembangan sosial pada anak yang ada pada lingkungan yang memiliki permasalahan dalam hal membaca dan berhitung. Perkembangan anak-anak sangat dipengaruhi oleh aktivitas bermain dan sosialisasi anak dengan teman sebaya. Tulisan ini menggunakan pendekatan kualitatif dengan desain studi kasus pada siswa sekolah dasar pada lingkungan social tertentu. Teknik pengumpulan data dalam tulisan ini menggunakan teknik observasi, wawancara, dan dokumentasi. Data yang diperoleh dianalisis dengan teknik analitik menggunakan langkah-langkah reduksi data, penyajian data, dan kesimpulan. Pengujian validitas data menggunakan uji kredibilitas dengan melakukan triangulasi bahan referensi dan cek anggota. Hasil penelitian menunjukkan bahwa dilihat dari hubungan lingkungan sosialnya, beberapa anak termasuk dalam kategori anak terlantar. Tetapi untuk beberapa anak lain, subjek termasuk dalam kategori anak yang ditolak. Dari aspek aktivitas, menunjukkan perilaku unik pada anak sekolah dasar. Dalam kondisi tersebut subjek tetap memainkan perilaku yang aktif di lingkungan sosialnya.
\end{abstract}

Kata kunci: Perkembangan, Anak Sekolah Dasar 


\section{A. Pendahuluan}

Perkembangan banyak dipandang sebagai proses yang terus menerus ataupun juga dinamis yang mana selalu dipengaruhi oleh sifat bawaan yaitu bakat individu dan juga dipengaruhi lingkungan sekitar dalam menentukan tinggkah laku apa yang akan diapreasikan dalam bentuk yang aktual dan dibentukan dalam suatu yang pasti. apabila dalam proses yang terus menerus ini hilang yang disebabkan oleh rusaknya bagian sifat bakat individu atau oleh kurangnya rangsangan yang mempengaruhi dalam lingkungan, atau oleh hambatan dalam hubungan interaksi sebab akibat bakat dan lingkungan, maka ini akan menimbulkan gangguan dalam perkembangan individu.

Sifat gangguan juga banyak timbul dipengaruhi oleh usia pada waktu gangguan itu datang memnghampiri individu. Seringkali juga gangguan itu menonjol pada salah satu aspek yang ada pada kepribadian individu, salah satu misal gangguan yang terjadi yaitu dalam jasmani dan psikomotorik individu, tak lupa juga dalam aspek intelektual, sosial, moral dan kadang kala juga terjadi dalam aspek emosional individu.

Dalam bagian tertentu gangguan intelektual yang sangat menonjol termasuk dalam bentuk-bentuk lemahnya ingatan yang sebagian disebabkan oleh kerusakan yang berada pada saraf pusat akan tetapi sebagian lain dapat disebabkan oleh pengaruh lingkungan dan tuntutan sosial. Lemah ingatan yang ringan yang nantinya akan dibicarakan inilah yang menjadi gangguan belajar anak sekolah dasar. Karena ini merupakan pengertian bahwa pada individu dalam kehidupan sehari-hari tidak dapat mengurusi dirinya sendiri.

Label terhadap lemah ingatan yang ringan sekarang ini apakah nantinya dapat diterapkan pada semua individu anak sekolah dasar yang keadaanya mengalami kesulitan belajar, dan sekarang mungkin disebut sukar belajar. Ini mengakibatkan kemungkinan ada faktor lain yaitu berupa dengan tuntutan sekolah yang harus dipenuhi setiap individu anak sekolah dasar.

Menutip dari JAKARTA, KOMPAS.com - Menteri Pendidikan dan Kebudayaan Muhadjir Effendy menyatakan banyak pihak yang masih salah memahami konsep 8 jam proses belajar mengajar di sekolah. Ia mengatakan, yang ada di benak masyarakat soal proses belajar mengajar selama 8 jam di sekolah ialah murid diberikan materi pelajaran selama 8 jam. Padahal, yang dimaksud proses belajar 8 jam tak hanya menerima pelajaran yang berasal dari buku teks, tetapi juga menerima pendidikan karakter. Ia menjelaskan, nantinya transfer pengetahuan dari buku teks hanya 30 persen. Sedangkan 60-70 persen sisanya akan diisi 
dengan pendidikan karakter. "Ini sebagai pemenuhan dari visi presiden yang menetapkan bahwa untuk pendidikan, terutama level pendidikan dasar SD dan SMP, diperbanyak pada penanaman budi pekerti dan pembentukan karakter," Muhadjir melanjutkan, ada beberapa karakter yang hendak dibentuk. Di antaranya, ada beberapa yang menjadi prioritas dari total 18 karakter, yakni jujur, pantang menyerah, toleran, dan gotong royong. Jadi sekali lagi 8 jam itu enggak berarti anak ada di kelas tetapi bisa di lingkungan sekitar sekolah bahkan di luar sekolah, yang penting semua jadi tanggung jawab sekolah di manapun anak belajar. ${ }^{1}$

\section{B. Metode Penelitian}

Researchers collect data through the method of documentation-observation. Then after the data collected, analyzed through content analysis and critical analysis and synchronized with cross-check the results of observation.

\section{Hasil Penelitian dan Pembahasan \\ Makna Perkembangan}

Pengertian perkembangan menunjuk pada suatu proses kearah yang lebih sempurna dan tidak begitu saja dapat diulang kembali. Perkemmbangan menunjuk pada perubahan yang bersifat tetap dan tidak dapat diputar kembali. ${ }^{2}$ Dalam pertumbuhan ada sementara ahli psikologis yang tidak membedakan antara perkembangan dan pertumbuhan, bahkan ada yang lebih mengutamakan pertumbuhan. ${ }^{3}$ Hal ini mungkin untuk menunjukan bahwa anak yang berkembang tadi bertambah kemampuannya dalam berbagai hal, lebih mengalami diferensial dan pada tingkat yang lebih tinggi, lebih mengalami integrasi. Dalam tulisan ini, maka istilah pertumbuhan khusus dimaksudkan untuk menunjukan bertambah besarnya ukuran badan dan fisik yang lebih murni. Menurut banyak ahli psikologi serta penulis sendiri, maka istilah perkembangan lebih dapat mencerminkan sifat yang khas mengenai gejala psikologis yang muncul.

Perkembangan juga berkaitan dengan belajar khususnya mengenai isi proses perkembangan, apa yang berkembang berkaitan dengan perilaku belajar. Disamping itu juga bagaimana hal sesuatu dipelajari, misalkan apakah melalui memorisasi atau hubungan

\footnotetext{
${ }^{1}$ Menteri Pendidikan dan Kebudayaan Muhadjir Effendy usai rapat koordinasi dengan Menteri Koordinator bidang Politik, Hukum dan Keamanan Wiranto di kantor Kemenko Polhukam, Jakarta Pusat, Kamis (8/12/2016)

${ }^{2}$ Werner, Einfahrung in die Entwicklungspychologie, Munchen: J.A. Barth, 1969.

${ }^{3}$ Umam, M. K. (2018, April). Reconstruction of Integrative Islamic Education in The Transformative Profetical Education Framework. In PROCEEDINGS: Annual Conference for Muslim Scholars (No. Series 1, pp. 511520).
} 
mengerti, ikut menentukan perkembangan. ${ }^{4}$ Dengan demikian perkembangan dapat diartikan sebagai proses yang kekal dan tetap menuju kea rah sesuatu organisasi pada tingkat integrasi yang lebih tinggi, berdasarkan pertumbuhan, pemasakan dan belajar. Terjadilah sesuatu organisasi atau struktur tingkah laku yang lebih tinggi.

Pengertian tingkah laku yang lebih tinggi berarti bahwa tingkah laku tadi mempunyai banyak diferensi, yaitu bahwa tingkaj laku tersebut tidak hanya lebih luas, melainkan mengandung kemungkinan yang lebih banyak. ${ }^{5}$ Pengertian organisasi atau struktur berarti bahwa di antara tingkah laku tadi ada saling hubungan yang bersifat khas dan menunjukan kekhususan anak pada suatu tingkat umur. Suatu definisi dari perkembangan adalah dalam proses tersebut sifat individu dan sifat lingkungan menentukan langkah tingkah laku apa yang akan menjadi aktual dan berwujud.

Perkembangan merupakan perubahan yang dialami seorang individu atau organisme menuju tingkan kematangannya yang berlangsung secara sistematis, profresif dan berkesinambungan. ${ }^{6}$ Sejalan dengan pendapat di atas, Chaplin berpendapat bahwa perkembangan adalah perubahan yang berkesinambungan dan progresif dalam organisme, mulai sejak lahir sampai mati. ${ }^{7}$ Menurut pendapat Hurlock progresif menandakan perubahan yang membimbing mereka maju dan bukan mundur. ${ }^{8}$ Sedangkan teratur dan koheren menunjukkan adanya hubungan nyata antara perubahan yang terjadi dan yang telah mengikuti.

Hurlock mengatakan bahwa perkembangan sosial adalah perolehan kemampuan berperilaku yang sesuai dengan tuntutan sosial. ${ }^{9}$ Sejalan dengan pendapat di atas, menurut pendapat Allen dan Marotz perkembangan sosial adalah area yang mencankup perasaan dan mengacu pada perilaku dan respon individu terhadap hubungan mereka dengan individu lain. $^{10}$

\footnotetext{
${ }^{4}$ Knoers A. M. P, Leren en ontwikkeling. A Continuing story. Info, Tijds chrift voor Onderwijswetansch, 1985, 40-60,

${ }^{5}$ Umam, M. K. (2018, February). Paradigma Pendidikan Profetik dalam Pendekatan Pembelajaran Tematik di Madrasah Ibtida'iyah. In PROCEEDING: The 3rd Annual International Conference on Islamic Education (Vol. 3, No. 1, pp. 120-132).

${ }^{6}$ Syamsu Yusuf. (2007). Psikologi Perkembangan Anak dan Remaja. Bandung: PT

Remaja Rosdakarya. 15.

${ }^{7}$ Desmita. (2005). Psikologi Perkembangan. Bandung: Remaja Rosdakarya. 4.

${ }^{8}$ Hurlock, Elizabeth B. (2000). Perkembangan Anak, (Alih bahasa: Med. Meitasari Tjandrasa dan Muslichah Zakarsih). Jakarta: Erlangga. 23.

${ }^{9} \mathrm{Ibid}, 250$.

${ }^{10}$ Allen, K. Eillen dan Marots, Lynn R. (2010). Profil Perkembangan Anak (Prakelahiran Hingga Usia 12 Tahun). Alih bahasa: Valentino. Jakarta: Indeks. 31.
} 
Menurut Hurlock untuk mencapai perkembangan sosial dan mampu bermasyarakat, seorang individu memerlukan tiga proses. ${ }^{11}$ Ketiga proses tersebut saling berkaitan, jadi apabila terjadi kegagalan dalam salah satu proses akan menurunkan kadar sosialisasi individu.

\section{Aspek Perkembangan Sosial Anak}

Havighurst mengungkapkan bahwa perjalanan hidup individu ditandai oleh adanya tugas-tugas yang harus dipenuhi dalam masa hidup tertentu sesuai dengan norma masyarakat dan norma kebudayaan. ${ }^{12}$ Tugas-tugas yang harus dipenuhi oleh individu tersebut disebut dengan tugas perkembangan. Hurlock mengungkapkan bahwa hal-hal yang diharapkan kelompok sosial terhadap anak-anak ditentukan dalam hubungannya dengan tugas perkembangan anak atau pengalaman belajar yang sesuai dengan tingkatan umur. ${ }^{13}$ Masa akhir kanak-kanak yaitu berkisar dari usia 6 hingga 12 atau 13 tahun yang biasa disebut dengan usia sekolah dasar. Menurut Izzaty, masa kanak-kanak akhir dibagi menjadi dua fase, yaitu sebagai berikut: ${ }^{14}$ (1) Masa kelas rendah Sekolah Dasar yang berlangsung antara usia 6/7 sampai 9/10 tahun yang biasanya duduk di kelas 1, 2, dan 3; (2) Masa kelas tinggi Sekolah Dasar yang berlangsung antara usia 9/10 sampai 12/13 tahun, serta biasanya duduk di kelas 4, 5, dan 6 .

Ciri-ciri anak masa kelas rendah Sekolah Dasar yaitu:

1. Ada hubungan yang kuat antara keadaan jasmani dan prestasi sekolah.

2. Suka memuji diri sendiri.

3. Apabila tidak dapat menyelesaikan suatu tugas atau pekerjaan, tugas tersebut dianggap tidak penting.

4. Suka membandingkan diri sendiri dengan orang lain, jika hal itu menguntungkan dirinya.

5. Suka meremehkan orang lain.

Tugas perkembangan anak usia sekolah menurut Havighurst yaitu sebagai berikut: (1) memiliki ketangkasan fisik yang diperlukan dalam melaksanakan permainan/olahraga; (2) membentuk sikap tertentu terhadap diri sendiri sebagai pribadi yang tumbuh dan berkembang; (3) belajar peranan sesuai jenis kelamin dan bergaul bersama teman sebaya; (4) belajar

\footnotetext{
${ }^{11}$ Hurlock, Elizabeth B. Perkembangan Anak..., 251.

${ }^{12}$ Monks, dkk. (2006). Psikologi Perkembangan (Pengantar dalam Berbagai Bagiannya). Yogyakarta: Gagjah Mada University Press, 22.

${ }^{13}$ Hurlock, Elizabeth B. (2000). Perkembangan Anak, (Alih bahasa: Med. Meitasari Tjandrasa dan Muslichah Zakarsih). Jakarta: Erlangga. 254.

${ }^{14}$ Rita Eka Izzaty. et. al. (2008). Perkembangan Peserta Didik. Yogyakarta: UNY Press, 116.
} 
membentuk sikap-sikap terhadap kelompok dan lembaga; (5) mengembangkan nurani, moralitas dan skala nilai; dan (6) belajar membaca, menulis, berhitung, serta belajar pengertian-pengertian kehidupan sehari-hari. ${ }^{15}$

Dalam tugas perkembangannya, perkembangan sosial anak usia sekolah ditandai dengan meluasnya lingkungan sosial. ${ }^{16}$ Senada dengan pendapat Piaget dalam masa akhir kanakkanak tersebut anak menjadi tidak bergantung pada orang tuanya karena hubungan pertemanan semakin meluas. ${ }^{17}$ Selaras dengan pendapat diatas, Izzaty menyatakan bahwa pemahaman tentang diri dan perubahan dalam perkembangan gender dan moral menandai perkembangan anak selama masa kanak-kanak akhir. Menurut Izzaty, perkembangan sosial masa kanak-kanak akhir dapat dilihat dari kegiatan bermain dan hubungan teman sebaya. ${ }^{18}$

Perkembangan sosial adalah perolehan kemampuan bertingkah laku sesuai tuntutan kelompok sosial. Perkembangan sosial anak yang optimal, akan memudahkan anak menyesuaikan dirinya dalam kelompok teman sebaya maupun dalam lingkunga masyarakat sekitar, baik dalam keiatan bermain maupun kegiatan-kegiatan sosial lainnya. Jadi, dapat disimpulkan bahwa perkembangan sosial anak usia sekolah dasar ditandai dengan pencapaian dalam aspek bergaul dengan teman sebaya, penyesuaian sosial, dan kegiatan bermain. Permasalahan belajar pada anak terhadap lingkungan

Permasalahan belajar meliputi anak-anak yang mempunyai kesulitan dalam mempelajari pengetahuan yang diharapkan diperoleh disekolah. Anak dengan permasalahan belajar biasanya mempunyai permasalah khusus. Namun dalam kelompok anak dengan permasalahan dan gangguan belajar ada juga mereka yang dipengaruhi oleh lingkungan sekitar dan pula mereka mempunyai kesulitan juga pada lebih dari satu bidang pelajaran seperti halnya anak yang sulit belajar. Mungkin lebih baik untuk melepaskan diri dari ketentuan apakah anak termasuk anak yang mengalami dengan gangguan belajar ataukah anak yang sulit belajar. Alangkah baiknya untuk menentukan pada bidang apa seorang anak menemukan kesulitan dlam belajar, misalnya membaca bagian apa dan berhitung bagian apa.

Berdasarkan observasi ditemukan anak yang permasalahanya belajar karena mereka mempunyai kesulitan dengan tugas-tugas belajar karena kurangnya strrategi kognitif tertentu.

\footnotetext{
${ }^{15}$ Monks, dkk. (2006). Psikologi Perkembangan (Pengantar dalam Berbagai Bagiannya). Yogyakarta: Gagjah Mada University Press, 23-24.

${ }^{16}$ Ibid, 183.

17 Allen, K. Eillen dan Marots, Lynn R. (2010). Profil Perkembangan Anak (Prakelahiran Hingga Usia 12 Tahun). Alih bahasa: Valentino. Jakarta: Indeks, 159.

${ }^{18}$ Rita Eka Izzaty. et. al. (2008). Perkembangan Peserta Didik. Yogyakarta: UNY Press, 114.
} 
Dengan demikian tidaklah berarti bahwa anak dengan permasalahan belajar tadi memiliki kapasitas ingatan yang terbatas, melainkan mereka tidak atau kurang menggunakan cara pengulangan untuk memahami sesuatu dalam ingatan jangka pendek. Dengan melatih anakanak tersebut dalam penggunaaan cara pengulangan dalam belajar maka mereka ternyata mampu mencapai prestasi normal dalam tugas tugas belajar. ${ }^{19}$ Mungkin anak-anak dengan permasalahan belajar kurang mengerti bagaimana cara menggunakan sistem kognitifnya sendiri. Bila mereka mengerti itu maka anak-anak yang mengalami permasalahan belajar mengerti dengan menghafal sesuatu lebih mudah dan bila objek yang dihafalkan itu dilakukan secara berulang ulang.

\section{Permasalahan Membaca Dan Berhitung Pada Anak Sekolah Dasar}

Seorang anak dengan permasalahan membaca disebut dengan disleksi. Anak-anak tersebut mempunyai keterbelakangan membaca yang besar dibandingkan dengan temantemannya sebaya dalam sekolah dasar.

Sebetulnya apa yang merupakan permasalahan disleksi adalah buta kata. Intinya bahwa permasalahan ini bersifat visual. Namun jarang sekali disleksi dilihat sebagai gangguan perifer dalam sistem visual, misalnya gangguan pada penglihatan, ${ }^{20}$ dan serta gangguan pada gerak mata. ${ }^{21}$ Untuk dapat dimengerti dimana letak permasalahannya akan diuraikan secara singkat mengenai proses belajar dan perkembangan membaca.

Kata-kata dalam prinsipnya dikenal dengan dua macam cara, cara pertama maka katakata dapat langsung dikenal melalui pola visual. Pada cara kedua, yaitu recodering fonologis, berjalan dengan cara tidak langsung. Maksudnya informasi visual diubah dulu dalam suara. ${ }^{22}$

Dengan ini berarti bahwa bunyi atau suara tadi itu dikaitkan pada huruf-huruf dan bahwa bunyi tadi mempunyai suara yang digabung menjadi kata. Dengan bunyi tadi maka kata-kata dapat dimengerti oleh anak sekolah dasar.

Pelatihan cara yang fonologis tadi makin efesien jika dilakukan lama kelamaan dan kata yang diucapkan dari pada dengan visual. Disamping itu pengenalan langsung juga hanya dapat dilakukan jika pada kata-kata sebelumnya telah dikenali oleh pembaca.

\footnotetext{
${ }^{19}$ Bray \& Tuner, The Rehearsal deficit hyphotesis dalam Ellis \& Bray, International Review of Research in Mental Retardation. Vol 14 (239-252) Orlando: Academic Press.

${ }^{20}$ Dumont, Dislexie, Theorie, Diagnosliek, behandling.Rutterdam: Lemniscaat, 1990.

${ }^{21}$ Stanovich, Discrepancy definition of reading disability, has intelegence led us astray? Reading research Quarterly. 1991, 360-407.

${ }^{22}$ Ibid, 360-407.
} 
Permasalahan berhitung pada anak sekolah dasar pada umumnya mempunyai keterbelakangan apakah permasalahan berhitung pada anak sekolah dasar berasal dari kekurangan dalam pengetahuan matematik atau memeng ada pengertian matematika kualitatif yang berlainan. ${ }^{23}$

Ada permasalahan berhitung pada anak sekolah dasar yakni abnormalitas neuropsikologis. Dalam beberapa penelitian yang dilakukan, maka anak-anak yang dengan permasalahan berhitung dibagai menjadi dua kelompok. Anak-anak yang disamping permasalahan tingkah laku tersebut juga bermasalah dalam membaca dan mengeja kata-kata, kelompok yang kedua adalah mereka yang mempunyai permasalahan hanya dalam berhitung saja. Kedua kelompok tersebut diberi berbagai tes yang mengukur kemampuan verbal, auditif, visual, senso motoris dan konseptual. Hasilnya bahwa kelompok satu hanya mengalami kesulitan pada tes verbal dan auditif, sedangkan kelompok kedua justru rendah prestasinya pada tes tes yang lain. Tugas tugas verbal dan audiktif mempunyai hubungan dengan otak bagian kiri. Tes tes yang lain itu berhubungan dengan otak bagian kanan. Jadi dapat disimpulkan bahwa kelompok satu mempunyai kelemahan atau deficiency pada otak bagian kiri, sedangkan deficiency tersebut pada kelompok kedua terjadi pada otak bagian kanan.

Menginterprestasikan perbedaan kedua masalah tersebut dalam tes sebagai petunjuk adanya penyebab neuropsikologis yang berbeda beda dan sesuatu yang sudah ada sejak lahir. Orang yang mempunyai permasalahan seperti kelompok kedua mempunyai permasalahan penyesuaian social yang mempunyai sebab neurospsikologis yang sama.

Sehingga langkah baiknya lebih mudah bila pendekatan tidak melalui dasar neuropsikologis tersebut melainkan dengan cara pengetahuan berhitungnya. ${ }^{24}$ Pengertian berhitung yaitu pengertian berhitung faktual dan berhitung melalui suatu cerita.

Berhitung factual berhubungan dengan otomatisasi pengertian yaitu mengerti jawaban hitungan sederhana dengan cepat. Sedangkan soal hitung dengan cara sebuah cerita disamping dibutuhkan pengertian berhitung juga dibutuhkan ketrampilan dalam penalaran dan bahasa.

\section{Simpulan}

Bahwa perkembangan adalah perubahan yang berkesinambungan dan progresif dalam organisme, mulai sejak lahir sampai mati. perkembangan sosial anak usia sekolah dasar

\footnotetext{
${ }^{23}$ Russel \& Ginsburg, Cognitive analysis of childrens mathematics difficulties.i Cognition and Instruction, 1, 217-244, 1984.

${ }^{24}$ Brown, Leven tegen dood, Utrecht: Ambo, 1972.
} 
ditandai dengan pencapaian dalam aspek bergaul dengan teman sebaya, penyesuaian sosial, dan kegiatan bermain.

Anak yang memiliki permasalahan belajar karena mereka mempunyai kesulitan dengan tugas-tugas belajar karena kurangnya strrategi kognitif tertentu. Dengan demikian tidaklah berarti bahwa anak dengan permasalahan belajar tadi memiliki kapasitas ingatan yang terbatas, melainkan mereka tidak atau kurang menggunakan cara pengulangan untuk memahami sesuatu dalam ingatan jangka pendek.

Sehingga berhitung factual berhubungan dengan otomatisasi pengertian yaitu mengerti jawaban hitungan sederhana dengan cepat. Sedangkan soal hitung dengan cara sebuah cerita disamping dibutuhkan pengertian berhitung juga dibutuhkan ketrampilan dalam penalaran dan bahasa. 


\section{Daftar Pustaka}

Allen, K. Eillen dan Marots, Lynn R. (2010). Profil Perkembangan Anak (Prakelahiran Hingga Usia 12 Tahun). Alih bahasa: Valentino. Jakarta: Indeks. 31.

Allen, K. Eillen dan Marots, Lynn R. (2010). Profil Perkembangan Anak (Prakelahiran Hingga Usia 12 Tahun). Alih bahasa: Valentino. Jakarta: Indeks, 159.

Bray \& Tuner, The Rehearsal deficit hyphotesis dalam Ellis \& Bray, International Review of Research in Mental Retardation. Vol 14 (239-252) Orlando: Academic Press.

Brown, Leven tegen dood, Utrecht: Ambo, 1972.

Desmita. (2005). Psikologi Perkembangan. Bandung: Remaja Rosdakarya. 4.

Dumont, Dislexie, Theorie, Diagnosliek, behandling.Rutterdam: Lemniscaat, 1990.

Hurlock, Elizabeth B. (2000). Perkembangan Anak, (Alih bahasa: Med. Meitasari Tjandrasa dan Muslichah Zakarsih). Jakarta: Erlangga. 23.

Hurlock, Elizabeth B. (2000). Perkembangan Anak, (Alih bahasa: Med. Meitasari Tjandrasa dan Muslichah Zakarsih). Jakarta: Erlangga. 254.

Hurlock, Elizabeth B. Perkembangan Anak..., 251.

Knoers A. M. P, Leren en ontwikkeling. A Continuing story. Info, Tijds chrift voor Onderwijswetansch, 1985, 40-60,

Menteri Pendidikan dan Kebudayaan Muhadjir Effendy usai rapat koordinasi dengan Menteri Koordinator bidang Politik, Hukum dan Keamanan Wiranto di kantor Kemenko Polhukam, Jakarta Pusat, Kamis (8/12/2016)

Monks, dkk. (2006). Psikologi Perkembangan (Pengantar dalam Berbagai Bagiannya). Yogyakarta: Gagjah Mada University Press, 22.

Monks, dkk. (2006). Psikologi Perkembangan (Pengantar dalam Berbagai Bagiannya). Yogyakarta: Gagjah Mada University Press, 23-24.

Remaja Rosdakarya. 15.

Rita Eka Izzaty. et. al. (2008). Perkembangan Peserta Didik. Yogyakarta: UNY Press, 116.

Rita Eka Izzaty. et. al. (2008). Perkembangan Peserta Didik. Yogyakarta: UNY Press, 114.

Russel \& Ginsburg, Cognitive analysis of childrens mathematics difficulties.i Cognition and Instruction, 1, 217-244, 1984.

Stanovich, Discrepancy definition of reading disability, has intelegence led us astray? Reading research Quarterly. 1991, 360-407.

Syamsu Yusuf. (2007). Psikologi Perkembangan Anak dan Remaja. Bandung: PT

Umam, M. K. (2018, April). Reconstruction of Integrative Islamic Education in The Transformative Profetical Education Framework. In PROCEEDINGS: Annual Conference for Muslim Scholars (No. Series 1, pp. 511-520).

Umam, M. K. (2018, February). Paradigma Pendidikan Profetik dalam Pendekatan Pembelajaran Tematik di Madrasah Ibtida'iyah. In PROCEEDING: The 3rd Annual International Conference on Islamic Education (Vol. 3, No. 1, pp. 120-132).

Werner, Einfahrung in die Entwicklungspychologie, Munchen: J.A. Barth, 1969. 